\title{
Pengembangan Video Pembelajaran PPKn Untuk Pengenalan Suku Dan Budaya Indonesia (Studi Kasus : Kelas IV Madrasah Ibtidaiyah Negeri 2 Buleleng)
}

Hairi Ardiansyah ${ }^{1}$, I Gede Partha Sindu ${ }^{2}$, I Made Putrama ${ }^{3}$

Program Studi Pendidikan Teknik Informatika

Jurusan Teknik Informatika

Fakultas Teknik dan Kejuruan

Universitas Pendidikan Ganesha

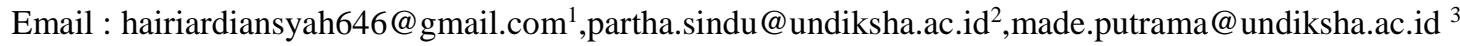

\begin{abstract}
Abstrak - Salah satu upaya untuk pengenalan suku dan budaya indonesia adalah dengan melalui pembelajaran PPKn pada kelas 4 MIN Singaraja. Dari hasil observasi dan wawancara awal ditemukan permasalahan pada pembelajaran pendidikan pancasila dan kewarganegaraan (PPKn) kelas 4 MIN Singaraja yang dimana siswa sulit untuk memahami materi keanekaragaman suku bangsa, media pembelajaran yang kaku yang berupa gambar, kurang mampu untuk menambah semangat dan memberikan contoh yang jelas, sehingga tujuan pembelajaran tidak optimal. Oleh sebab itu peneliti merasa sangat perlu untuk mengembangkan sebuah media pembelajaran yang dapat membantu proses pembelajaran pengenalan suku budaya. Pengembangan media ini dirasa akan membantu karena dalam video pembelajaran pengenalan suku budaya yang diusulkan akan menampilkan sebuah gambar yang bergerak atau video yang memberikan contoh - contoh keberagaman indonesia dan suku budaya indonesia seperti suku, rumah adat, pakaian adat, tarian, alat musik yang sesuai dengan kenyataan dunia nyata. Dalam media video pembelajaran ini juga akan di jelaskan tentang masing suku budaya, mulai dari penjelasan rumah adat, pakaian adat, alat musik, tari, dan sebagainya. Sehingga mempermudah siswa dalam memahami contoh dan penjelasan suku bangsa indonesia. Pengembangan media pembelajaran pengenalan suku budaya ini menggunakan model ADDIE. Pengembangan produk dengan model ini dapat menghasilkan produk yang baik, karena pada setiap fase yang dilalui dapat dilakukan evaluasi. Beberapa pengujian dilakukan untuk mengetahui tingkat keefektifan media pembelajaran pengenalan suku budaya indonesia yang di antaranya ialah uji ahli isi dengan hasil $100 \%$ sesuai, uji ahli media dengan representasi $100 \%$ sesuai, uji efektifitas dengan hasil $89,3 \%$ yang berarti media ini sangat efektif, uji guru dengan hasil $92 \%$ dan uji respon pengguna dengan hasil sebesar $89,07 \%$ yang menandakan media ini masuk kategori sangat positif.
\end{abstract}

Kata Kunci : Pembelajaran PPKn, ADDIE, Media Pembelajaran

Abstract-One of the efforts to introduce Indonesian tribes and culture is through learning PPKn at 4th grade MIN Singaraja. From the results of observations and preliminary interviews found problems in the learning of Pancasila and Citizenship Education (PPKn) class 4 MIN Singaraja where students find it difficult to understand the diversity of ethnic groups, rigid learning media in the form of pictures, less able to increase enthusiasm and provide clear examples, so that learning objectives are not optimal. Therefore, researchers feel it is very necessary to develop a learning media that can help the process of learning ethnic cultural introduction. The development of this media is felt to be helpful because in the proposed video introduction to cultural ethnics it will display a moving picture or video that provides examples of Indonesian diversity and Indonesian cultural tribes such as tribes, traditional houses, traditional clothing, dances, musical instruments that are in accordance with real world reality. In this learning video media will also be explained about each ethnic group, starting from the explanation of traditional houses, traditional clothing, musical instruments, dance, and so on. So as to facilitate students in understanding the examples and explanations of the Indonesian tribes. The development of learning media for introducing ethnic culture uses the ADDIE model. Product development with this model can produce good products, because each phase can be evaluated. Several tests were carried out to determine the effectiveness of Indonesian culture of tribal recognition learning media which included the content expert test with $100 \%$ appropriate results, expert media testing with $100 \%$ appropriate representation, effectiveness test with $89.3 \%$ results which meant that the media was very effective, test the teacher with $92 \%$ results and test the response of the user with 
a result of $89.07 \%$ which indicates that this media is in a very positive category.

Keywords: PPKn learning, ADDIE, learning media

\section{PENDAHULUAN}

Pendidikan merupakan upaya yang penting untuk memajukan bangsa dalam suatu negara sehingga bisa tetap bersaing dengan negara lain terkait semakin berkembangnya zaman saat ini. Upaya pemerintah dalam memajukan kehidupan bangsa yang berkualitas dan kompetitif telah diatur dalam Undang-Undang Sistem Pendidikan Nomor 20 tahun 2003 pasal 1, yaitu pendidikan adalah usaha sadar dan terencana untuk mewujudkan suasana belajar dan proses pembelajaran agar peserta didik secara aktif mengembangkan potensi dirinya untuk memiliki kekuatan spiritual keagamaan, pengendalian diri, kepribadian, kecerdasan, akhlak mulia, serta ketrampilan yang diperlukan dirinya, masyarakat, bangsa dan Negara [1].

Bangsa Indonesia adalah bangsa yang terdapat beranekaragam budaya, bahasa, suku, dan agama. Daerah geografis Indonesia yang terdiri dari kepulauan-kepulauan membuat suatu keanekaragaman dalam bidang sosial, budaya dan politik masyarakat Indonesia. Karena keanekaragaman inilah yang menjadi latar belakang semboyan bangsa Indonesia yaitu Bhineka Tunggal Ika. Hal ini menunjukkan bahwa masyarakat Indonesia adalah masyarakat yang bhineka (beranekaragam). Ke-bhineka-an masyarakat Indonesia harus terus dijaga agar dapat mewujudkan persatuan dan kesatuan seluruh bangsa Indonesia. Beranekaragam suku bangsa hidup berdampingan dengan latar belakang kehidupan yang berbeda menjadikan masyarakat di Indonesia memiliki kehidupan yang beranekaragam pula yang dipengaruhi oleh budaya masingmasing sebagai warisan dari tiap generasi sebelumnya. Keanekaragaman adalah istilah yang digunakan untuk menjelaskan pandangan seseorang tentang ragam kehidupan di dunia, ataupun kebijakan kebudayaan yang menekankan tentang penerimaan terhadap adanya keragaman, dan berbagai macam budaya (multikultural) yang ada dalam kehidupan masyarakat menyangkut nilai-nilai, sistem, budaya, kebiasaan, dan politik yang mereka anut [2].

Salah satu upaya untuk pengenalan suku dan budaya indonesia adalah dengan melalui pembelajaran PPKn pada kelas 4 MIN Singaraja. Pasal 37 Undang - Undang Republik Indonesia (UURI) Nomor 20 Tahun 2003 tentang Sistem Pendidikan Nasional (UU Sisdiknas) menjelaskan bahwa Pendidikan Kewarganegaraan (PKn) adalah salah satu mata pelajaran yang wajib terdapat pada kurikulum pendidikan dasar dan menengah. Dalam lampiran Peraturan Menteri Pendidikan Nasional (Permendiknas) Nomor 22 Tahun 2006 tentang Standar Isi dijelaskan bahwa "mata pelajaran Pendidikan Kewarganegaraan merupakan pelajaran yang memfokuskan pada pembentukan warga negara yang memahami dan mampu melaksanakan hak - hak dan kewajibanya untuk menjadi warga negara Indonesia yang cerdas, terampil, dan berkarakter yang diamatkan oleh Pancasila dan UUD 1945".

Dari pengertian di atas dapat diketahui bahwa pada dasarnya dengan diwajibkannya mata pelajaran Pendidikan Kewarganegaraan terutama disekolah dasar diharapkan dapat membentuk generasi muda calon penerus bangsa yang berlandaskan Pancasila dan UUD 1945. Yakni generasi muda yang memiliki rasa cinta terhadap tanah air dengan berbagai macam karakter suku dan bangsa yang berbeda beda dan mampu saling bekerja sama dalam mencapai suatu tujuan tanpa memandang suku dan budaya yang sama

Berdasarkan observasi dan wawancara yang peneliti lakukan di kelas 4 MIN Singaraja, dalam pembelajaran Pendidikan Pancasila dan Kewarganegaraan (PPKn) kelas 4 MIN yang dimana siswa sulit untuk memahami materi Keanekaragaman Suku Bangsa, Sosial, dan Budaya sebab untuk contoh - contoh suku dan budaya indonesia hanya diberikan contoh berupa sebuah gambar depan dari suku dan budaya tersebut. Media pembelajaran yang kaku yang berupa gambar, kurang mampu untuk menambah semangat dan memberikan contoh yang jelas, sebab dalam pembelajaran PPKn kelas 4 MIN Singaraja terdapat materi seperti rumah adat, pakaian adat, alat musik daerah, makanan khas daerah, senjata tradisional dan tarian daerah harus di berikan contoh seperti contoh nyata dari suku dan budaya tersebut. Dari hasil observasi dan wawancara dengan guru PPKn kelas 4 MIN Singaraja, diketahui bahwa alat atau media serta buku untuk memberikan contoh seperti rumah adat, pakaian serta senjata tradisional masih kurang optimal, ketersediaan buku cetak maupun media lainnya masih sangat minim sekali disekolah MIN Singaraja. Alternatif yang dilakukan oleh Guru kelas 4 MIN Singaraja pada pembelajaran keanekaragaman suku dan budaya di Indonesia adalah dengan menggunakan buku pembelajaran, dimana buku yang di ajar memiliki sedikit konteks gambar tentang contoh keanekaragaman suku dan budaya Indonesia. Selain buku, alternatif yang digunakan adalah mebuat siswa mencari sendiri contoh dan materi di dalam Internet, cara ini masih kurang baik karena siswa sulit mengakses internet dan sulit menggunakan komputer, contoh yang didapatkan sedikit dan gambar yang digunakan sebagai contoh pembelajaran dirasa kurang optimal. Gambar tidak memberikan contoh yang memuaskan dan menyulitkan siswa dalam membedakan rumah adat yang satu dengan yang lainnnya, karena terdapat dua gambar yang memiliki contoh yang hampir sama dan membuat siswa kesulitan membandingkan rumah adat tersebut, gambar mudah rusak, dan tidak abstrak. Sehingga tujuan pembelajaranpun tidak optimal dan siswa kurang mampu memahami contoh suku dan budaya indonesia. Untuk itu sangat diperlukan media yang 
bisa untuk mendukung pembelajaran yaitu khususnya Keanekaragaman Suku dan Budaya di Indonesia dengan menggunakan media video pembelajaran.

Berdasarkan analisis masalah tersebut maka solusi yang dapat peneliti usulkan adalah dengan mengembangkan sebuah video pembelajaran PPKn untuk pengenalan suku dan budaya indonesia. Pengembangan media ini dirasa akan membantu karena dalam video pembelajaran pengenalan suku budaya yang diusulkan akan menampilkan sebuah gambar yang bergerak atau video yang memberikan contoh - contoh keberagaman indonesia dan suku budaya indonesia seperti suku, rumah adat, pakaian adat, tarian, alat musik yang sesuai dengan kenyataan. Penelitian terkait seperti [3] dan [4]. Juga menganggap bahwa cara efektif untuk membantu proses pembelajaran iadalah dengan menerapkan media pembelajaran.

\section{KAJIAN TEORI}

\section{A. Hakekat Pembelajaran PPKn}

Pendidikan Kewarganegaraan (Citizenship) merupakan mata pelajaran yang memfokuskan pada pembentukan diri yang beragam dari segi agama, sosio-kultural, bahasa, usia dan suku bangsa untuk menjadi warga negara yang cerdas, terampil, dan berkarakter yang diamanatkan oleh Pancasila dan UUD 1945. Berdasarkan Permendiknas No. 22 Tahun 2006 tentang strandar isi, dijelaskan pula PKn sebagai bagian dari kelompok mata pelajaran kewarganegaraan dan kepribadian dimaksud untuk peningkatan kesadaran dan wawasan peserta didik akan status, hak dan kewajibannya dalam kehidupan bermasyarakat, berbangsa dan bernegara serta peningkatan kualitas dirinya sebagai manusia. Pendidikan Kewarganegaraan dapat diartikan sebagai wahana untuk mengembangkan dan melestarikan nilai luhur dan moral yang berakar pada budaya bangsa Indonesia yang diharapkan dapat diwujudkan dalam bentuk perilaku kehidupan seharihari peserta didik sebagai individu, anggota masyarakat dalam kehidupan berbangsa dan bernegara [5].

\section{B. Suku Budaya}

Dalam [6] menyatakan Sukubangsa adalah golongan sosial yang askriptif berdasarkan atas keturunan dan tempat asalnya. Dengan demikian, jati diri sukubangsa atau kesukubangsaan adalah jati diri yang askriptif yang didapat bersamaan dengan kelahiran seseorang atau tempat asalnya. Kesukubangsaan berbeda dari berbagai jati diri lainnya yang dipunyai oleh seseorang, karena kesukubangsaan bersifat primordial (yang pertama didapat dan menempel pada diri seseorang sejak masa kanak-kanaknya dan utama dalam kehidupannya karena merupakan acuan bagi jati diri dan kehormatannya). Berbagai jati diri lain yang dipunyai oleh seseorang berdasarkan pada perolehan status dalam kehidupan sosialnya. Berbagai jati diri lainnya dapat hilang karena tidak berfungsinya status - status yang dipunyai seseorang, sedangkan jati diri sukubangsa atau kesukubangsaan tidak dapat hilang. Bila jati diri sukubangsa tidak digunakan dalam interaksi, jati diri sukubangsa atau kesukubangsaan tersebut disimpan, dan bukannya dibuang atau hilang.

Ditinjau dari asal katanya, Budaya atau Kebudayaan berasal dari bahasa Sansekerta yaitu "budhayah" yang merupakan bentuk jamak dari "budhi" yang berarti 'budi' atau 'akal'. Sehingga Koentjaraningrat (1990:181) mendefinisikan budaya sebagai daya dari budi berupa cipta, karsa dan rasa. Sedangkan budi diartikan sebagai hal-hal yang berkaitan dengan akal manusia yang merupakan pancaran dari budi dan daya terhadap seluruh apa yang dipikir, dirasa, dan direnungkan yang kemudian diamalkan dalam bentuk suatu kekuatan yang menghasilkan kehidupan. Dalam Kamus budaya adalah pikiran, akal budi, hasil. Sedangkan kebudayaan adalah hasil kegiatan dan penciptaan batin (akal budi) manusia (seperti kepercayaan, kesenian dan adat istiadat) [7].

\section{Media Pembelajaran}

Secara harfiah, media berarti perantara atau pengantar Kata media berasal dari bahasa latin medius yang secara harfiah berarti "tengah", "perantara", atau "pengantar". Dalam bahasa Arab, media adalah perantara atau pengantar pesan dari pengirim kepada penerima pesan (Arsyad, 2011). Pada pengertian lain, media adalah segala sesuatu yang dapat digunakan utuk menyampaikan pesan dari pengirim ke penerima pesan (Prawiradilaga, 2008). Menurut Gagne (1992), media adalah berbagai jenis komponen dalam lingkungan siswa yang dapat merangsangnya untuk belajar. Senada dengan pendapat Gagne, Briggs mendefinisikan media pembelajaran sebagai bentuk fisik yang dapat menyajikan pesan yang dapat merangsang siswa untuk belajar. Dari dua definisi ini tampak pengertian media mengacu pada penggunaan alat yang berupa benda untuk membantu proses penyampaian pesan. Sementara itu Asosiasi Pendidikan Nasional (Nation Education Association/ NEA) memberikan batasan tentang media yaitu bentuk-bentuk komunikasi baik tercetak maupun audi visual serta bebagai peralatannya. Media pendidikan adalah sumber belajar dan dapat juga diartikan dengan manusia dan benda atau peristiwa yang membuat kondisi siswa mungkin memperoleh pengetahuan, keterampilan atau sikap. Selain alat yang berupa benda, yang digunakan untuk menyalurkan pesan dalam proses pendidikan, pendidikan sebagai figur sentral atau model dalam proses interaksi edukatif merupakan alat pendidikan yang juga harus di perhitungkan.

Menurut [8] untuk mengembangan media pembelajaran perlu diperhatikan prinsip VISUALS, yang dapat digambarkan 
sebagai singkatan kata - kata : [1] Visible : Mudah dilihat. [2] Interesting : Menarik. [3] Simple : sederhana. [4] Useful : isinya berguna/bermanfaat [5] Accurate : benar (dapat dipertanggung jawabkan). [6] Legitimate : Masuk akal/sah [7] Structured : terstruktur / tersusun dengan baik.

\section{Video}

Video merupakan media audio visual yang sudah beredar di masyarakat dan banyak diminati oleh anak - anak sekolah dasar, mulai dari jenis video hiburan, pengetahuan, informasi, musik dan cerita - cerita bersejarah bisa di saksikan dengan mudah [9]. Media audio visual adalah media yang mempunyai unsur suara dan unsur gambar. Jenis media ini mempunyai kemampuan yang lebih baik karena meliputi suara dan gambar [10].

Video adalah system gambar hidup atau gambar bergerak yang saling berurutan. Terdapat dua macam video yaitu video analog dan video digital. Video analog dibentuk dari deretan sinyal elektrik (gelombang analog) yang direkam oleh kamera dan dipancarluaskan melalui gelombang udara. Sedangkan video digital dibentuk dari sederetan sinyal digital yang berbentuk, yang menggambarkan titik sebagai rangkaian nilai minimum atau maksimum, nilai minimum berarti 0 dan nilai maksimum berarti 1 [11].

\section{METODOLOGI PENELITIAN}

Media pembelajaran pengenalan suku dan budaya dikembangkan menggunakan model ADDIE (Analyze, Design. Development, Implementasi, and Evaluation). Sesuai dengan namanya, model ADDIE terdiri dari lima tahapan yaitu tahapan Analyze, Design. Development, Implementation, and Evaluation. Berikut ini penjabaran tentang penelitian pengembangan media pembelajaran pengenalan tentang suku dan budaya indonesia.

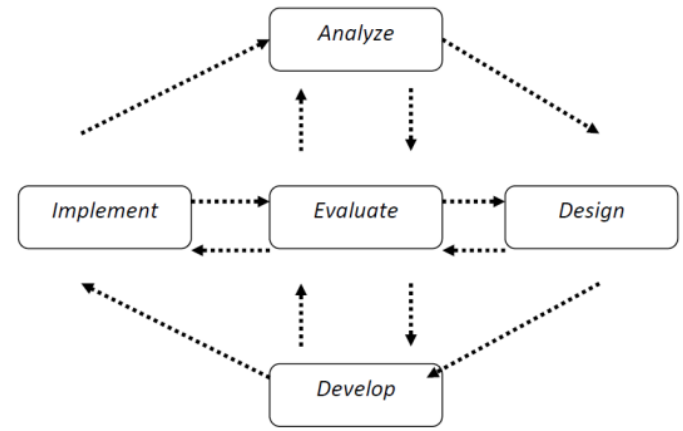

Gambar 1. Model Penelitian ADDIE
Tahapan Analyze pada penelitian Pengembangan media video pembelajaran "SUKU dan BUDAYA INDONESIA" di MIN SINGARAJA" terdiri dari proses teknik pengumpulan data, standar kompetensi, sinopsis, kebutuhan fungsional, kebutuhan non fungsional, analisis alat, analisis STP dan analisis SWOT.

\section{B. Design}

Pada tahap ini peneliti melakukan perancangan Media seperti penyusunan jadwal, pembuatan design concept art, storyboard, pemilihan pengisi suara, perekaman dialog, pembuatan musik dan efek suara.

\section{Development}

Pada tahap ini peneliti melakukan pengembangan media dengan mengembangkan tampilan antarmuka. dan membuat hasil dari tahap development.

\section{Implementation}

Pada tahap ini penliti melakukan implementasi yaitu dengan melakukan penentuan kebutuhan perangkat keras, kebutuhan perangkat lunak dan membuat hasil tahap implementasi.

\section{E. Evaluation}

Pada tahap ini peneliti melakukan evaluasi terhadap seluruh terhadap semua tahap analysis, design, development dan implementation.

\section{HASIL \& PEMBAHASAN}

\section{Hasil Penelitian}

Hasil evaluasi model penelitian merupakan proses menjalankan dan mengevaluasi sebuah perangkat lunak berdasarkan model penelitian yang digunakan untuk menguji apakah perangkat lunak sudah memenuhi persyaratan atau belum untk mementukan perbedaan antara hasil yang diharapkan dengan hasil sebenarnya.

Berikut ini akan dijabarkan mengenai beberapa tahapan terkait dengan hasil evaluasi dari media pembelajaran pengenalan suku budaya indonesia diantaranya yaitu tahap Analysis (analisa), tahap Design (desain), tahap Development (pengembangan), tahap Implementation (implementasi), dan tahap Evaluation (evaluasi).

\section{A. Analisis}

Disini peneliti melakukan analisi kebutuhan tentang pembatasan masalah dari media yang dibuat dengan memperhatikan ketersediaan waktu dan kemampudan dari pembuat media pembelajaran, serta hal-hal apa yang dibutuhkan dalam pembuatan media pembelajaran tersebut

- Hasil analisis ketertarikan 
Analisi Karakteristik atau Ketertarikan Anak-Anak terhadap video pembelajaran PPKn pengenalan suku dan budaya indonesia. di lakukan dengan cara menyebarkan angket kepada 30 siswa, angket yang di sebarkan merupakan acuan utama dalam pengembangan video pembelajaran kemudian hasil terbanyak dari model yang di pilih oleh anakanak yang akan di jadikan acuan pembentukan media.

- Kebutuhan fungsional

Adapun hasil analisis kebutuhan fungsional meliputi :[1] Video pembelajaran "Pengenalan Suku Budaya Indonesia" memiliki 3 tempat adegan yang berbeda - beda. [2] Video pembelajaran "Pengenalan Suku Budaya Indonesia" terdiri dari 1 pengisis suara (karakter) tiap masing - masing karakter. [3] Video pembelajaran "Pengenalan Suku Budaya Indonesia" memberikan 5 contoh suku budaya indonesia yang terdiri dari pulau (jawa, bali, toraja, papua dan minang kabau). [4] Pergerakan kamera Video pembelajaran "Pengenalan Suku Budaya Indonesia" hanya diam dan statis. [5] Pengambilan gambar dalam Video pembelajaran "Pengenalan Suku Budaya Indonesia" hanya medium, closes up dan longshot.

- Kebutuhan non fungsional

Dan hasil analisis kebutuhan fungsional meliputi : [1] Video pembelajaran "Pengenalan Suku Budaya Indonesia" mampu menampilkan logo UNDIKSHA, logo jurusan PTI dan logo LCI diawal video. [2] Video pembelajaran "Pengenalan Suku Budaya Indonesia" menampilkan contoh cerita yang nyata. [3] Video pembelajaran "Pengenalan Suku Budaya Indonesia" mampu memperdengarkan suara dan dialog berbahasa indonesia dengan jelas. [4] Video pembelajaran "Pengenalan Suku Budaya Indonesia" mampu meberikan contoh dengan menjelaskan masing - masing contoh

- Analisis alat

Peralatan yang digunakan dalam pembuatan Video Pembelajaran PPKn Untuk Pengenalan Suku dan Budaya Indonesia adalah sebagai berikut :[1] 1 buah scanner. [2] 1 buah laptop dengan spesifikasi core i5 dengan RAM 8 GB Dan VGA Card 2 GB NVIDIA Geforce 940MX. [3] Komputer dengan Spesifikasi core i7 dengan RAM 16 GB. Dan VGA Card 4 GB NVIDIA Gefore 1080 .[4] 1 buah microphone [5] 1 buah headset Alat tulis dan gambar

- Hasil analisis STP

Analisis STP sangat penting untuk menentukan target penonton. Segmentation dan targeting merupakan pembagian target penonton berdasarkan letak Geografis, Segi Demografis, Serta Segi Psikografis. Sedangkan positioning merupakan penempatan karya dalam fungsinya untuk penonton. Video pembelajaran pengenalan suku dan budaya Indonesia memiliki target penonton yaitu dari segi geografis target penonton diperuntukan untuk wilayah Indonesia karena isi cerita suku dan budaya Indonesia menggambarkan karateristik masing - masing daerah yang ada di pulau Indonesia. Segi demografis Video pembelajaran pengenalan suku dan budaya Indonesia di tunjukan kepada penonton siswa - siswi kelas 4 SD/MIN karena dalam pembelajaran PPKn kelas 4 SD/MIN memiliki kesamaan materi dengan Video pembelajaran suku dan budaya Indonesia. Segi psikografis penonton yang dituju adalah motivasi belajar, minat dan dayatarik dalam Video pembelajaran suku dan budaya Indonesia. Tahap analisis STP selanjutnya adalah positioning, Video pembelajaran pengenalan suku dan budaya Indonesia adalah Video pembelajaran yang mendidik sehingga diharapkan penonton memperoleh tiga aspek yaitu hiburan, pendidikan karakter dan pengetahuan mengenai suku dan budaya Indonesia hiburan diperoleh dari alur cerita serta tokoh yang menarik pada Video pembelajaran. Pendidikan karakter diperoleh dari pesan moral yang terdapat pada Video pembelajaran dan pengetahuan mengenai suku dan budaya Indonesia diperoleh dari contoh - contoh suku dan budaya Indonesia yang di tampilkan pada Video pembelajaran pengenalan suku dan budaya Indonesia.

- Hasil analisis SWOT

Analisis SWOT dilakukan untuk mengetahui kekuatan, kelemahan, kesempatan yang bisa didapat, serta ancaman yang mungkin terjadi pada media pembelajaran tersebut. Kekuatan dari media video pembelajaran ini adalah Video pengenalan suku dan budaya ini merupakan video yang mendidik. Meningkatkan pengetahuan siswa tentang suku dan budaya Indonesia. Membangun rasa cinta terhadap suku dan budaya Indonesia Video ini memberikan contoh suku dan budaya yang nyata (tidak dalam bentuk gambar).

Kelemahan dari media pembelajaran pengenalan suku budaya indonesia adalah Keterbatasan contoh suku dan budaya Indonesia, Keterbatasan biaya produksi Video, Crew yang terbatas dan masih amatir atau dalam proses pembelajaran.

Peluang dari media pembelajaran pengenalan suku budaya indonesia adalah Video suku dan budaya Indonesia ini berpeluang untuk dijadikan media pembelajaran bagi sekolah dasar di matapelajaran PPKn dan Sejarah. Peluang Video ini di tonton sangat besar karena merupakan video pembelajaran pertama yang mengangkat suku dan budaya dengan contoh suku dan budaya yang nyata.

Tantangan dari media pembelajaran pengenalan suku budaya indonesia adalah Suku dan budaya indoesia belum begitu terkenal, Contoh suku dan budaya indonesia hanya bergantung pada satu tempat

\section{B. Desain}

Tahapan Design pada Pengembangan video pembelajaran PPKn "Pengenalan Suku dan Budaya Indonesia" terdiri dari penyusunan jadwal, pembuatan design concept art, pembuatan storyboard, pemilihan pengisi suara, perekaman dialog, pembuatan animatic, pembuatan musik dan efek suara.

- Design konsep art 
Pada video pembelajaran PPKn Pengenalan Suku dan Budaya Indonesia Rancangan lingkungan video, penulis buat berdasarkan lingkungan suku budaya yang terdapat pada taman nusa yang berlokasikan di Gianyar, serta kondisi lingkungan seperti taman soekarno yang berlokasikan di Buleleng.

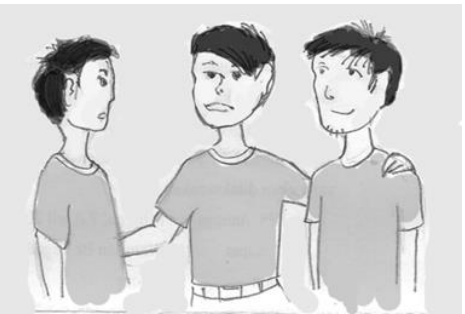

Gambar 2. Contoh karakter

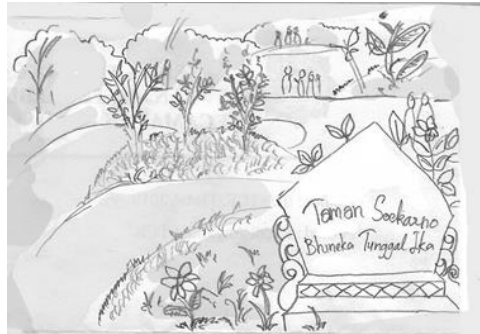

Gambar 3. Lingkungan taman soekarno

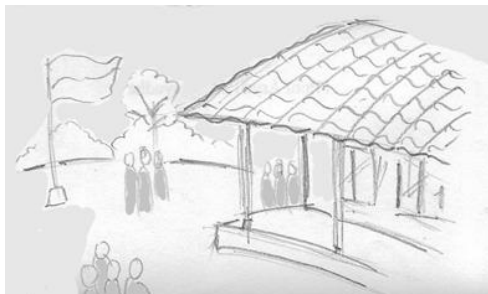

Gambar 4. Lingkungan sekolah

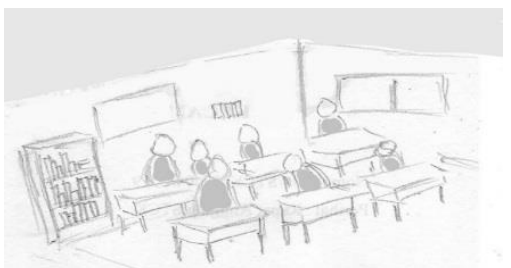

Gambar 5. Dalam kelas

\section{Pengembangan}

Pada tahapan ini dilakukan pengembangan dari tahap desain adapun pengembangan yang di lakukan adalah pengembangan desain dan di implementasikan kedalam bentuk animasi, hasil pengembangan bisa di lihat pada penjelasan di bawah.

- Hasil Layar Opening

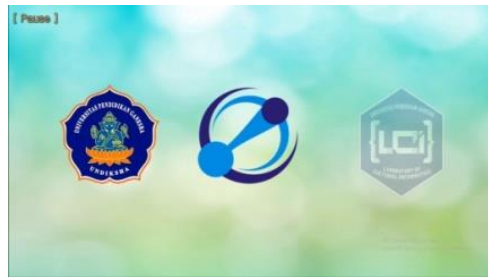

Gambar 6. opening

- Layar antar muka lingkungan taman soekarno

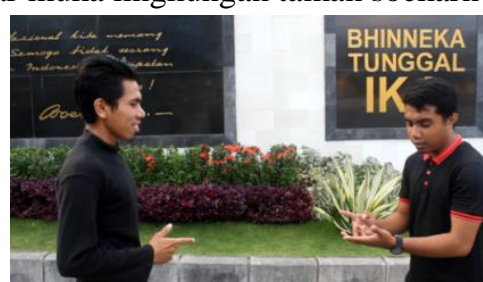

Gambar 7. taman soekarno

- Layar antar muka lingkungan di dalam kelas

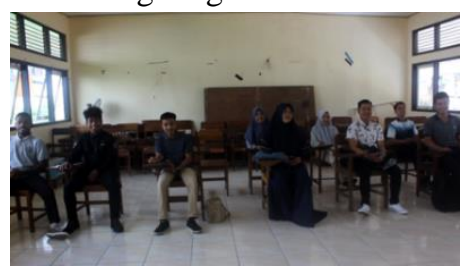

Gambar 8. Dalam kelas

- Layar antar muka karakter

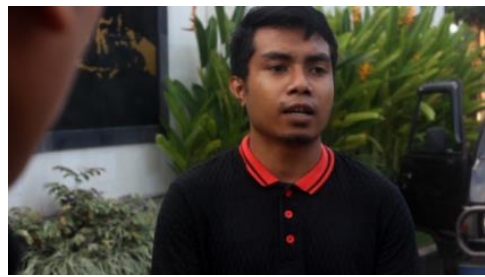

Gambar 9. Karakter

- Layar antar muka suku budaya

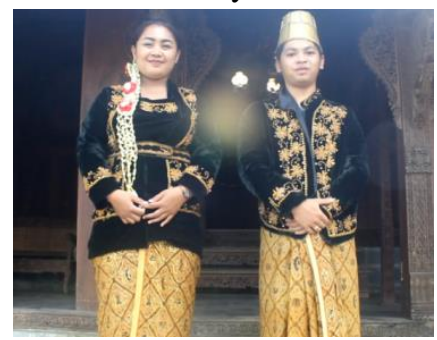

Gambar 10. Pakaian adat jawi jangkep 


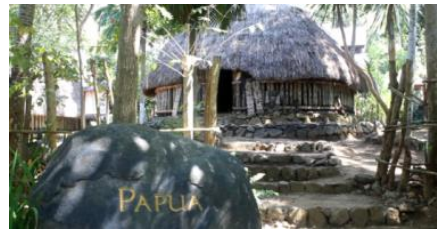

Gambar 11. Rumah adat honai

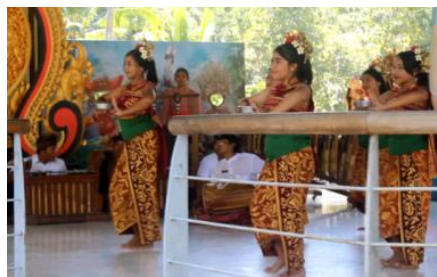

Gambar 12. Tari pendet

D. Implementasi

Tahapan selanjutnya adalah tahap Implementation (Implementasi). Tahap ini adalah tahap pengujian kelayakan produk dengan tujuan untuk memastikan media yang telah dibangun berdasarkan rancangan yang dibuat, sudah benar dan sesuai dengan rancangan ataupun materi pembelajaran, Berikut adalah hasil pengujian yang telah dilakukan yaitu :

- Uji validitas

Pada uji validitas ini dilakukan pengecekan antara kesesuaian isi dan media yang telah di bangun materi pembelajaran dan contoh nyata suku budaya idnonesia. Sedangkan oleh ahli media,desain ini sendiri dilakukan untuk pengecekan kesesuaian rancangan dengan hasil implementasi pada media.

- Uji ahli is, ahli media dan desain

Pengujian uji ahli isi dilakukan oleh orang yang benar benar mengetahui dan mengerti pelajaran PPKn pengenalan suku dan budaya. Dalam hal ini para ahli ini diantaranya guru kelas 4 SD atau guru SD yang pernah mengajar tentang suku budaya indonesia.. Sedangkan pelaksanaan uji ahli media, desain dalam hal ini yang memahami aspek dalam media. Para ahli yang akan menguji media pembelajaran pengenalan suku dan budaya berbasi video adalah dosen di Undiksha.

- Uji respon pengguna

Pelaksanaan uji respon pengguna dalam hal ini adalah siswa kelas 4 MIN singaraja, yang sebelumnya sudah peneliti gunakan untuk menguji karakteristik, pre test, dan post test.

- Uji respon guru

Pelaksanaan uji respon guru dalam hal ini peneliti menggunakan satu guru saja sebagai patokan. Dengan 10 pernyataan dalam angket

E. Evaluasi

Berdasarkan pengujian yang dilakukan akan menentukan apakah media pembelajaran pengenalan suku dan budaya indoensia dikatakan layak atau tidak layak digunakan. Pada tahap evaluasi ini semua hasil angket akan dipaparkan dan dievaluasi hasilnya.

- Hasil uji validitas ahli isi dan media

Pada tahap uji ini, pengujian dilakukan oleh dua orang ahli isi yang merupakan guru kelas SD, pengujian juga dilakukan oleh dua ahli media, desain yang merupakan dosen di Undiksha. kemudian hasil yang di dapat dari 1 tahap pengujian yaitu $100 \%$ sesuai.

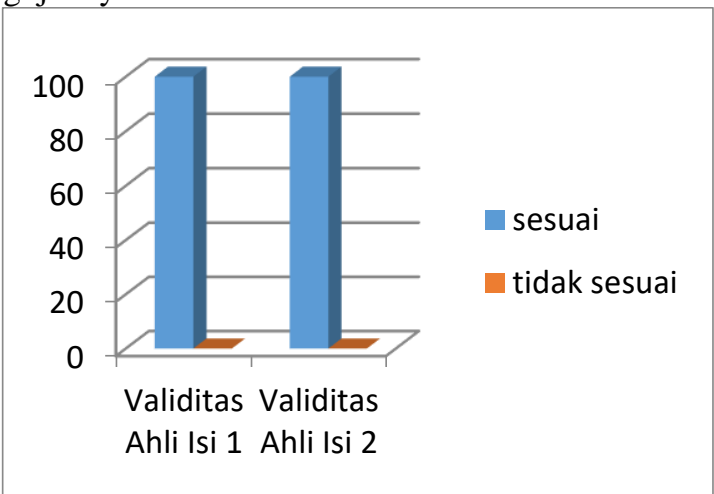

Gambar 13 Uji Validitas Ahli Isi

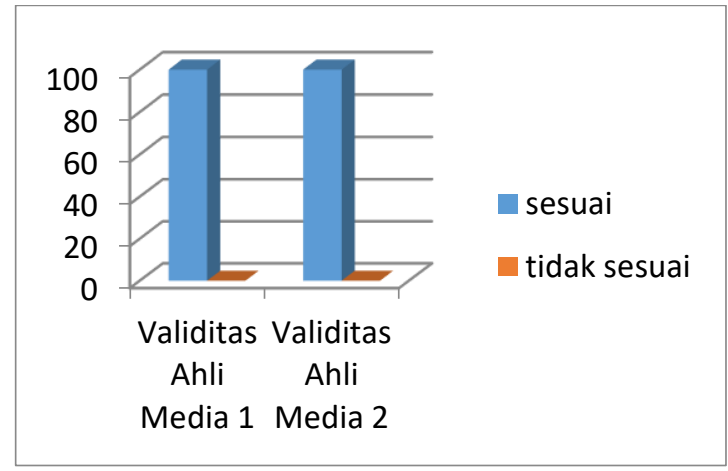

Gambar 14 Uji Validitas Ahli

Media dan Design

- Hasil uji ahli isi dan media

Pada tahapan uji ahli isi ini menggunakan angket yang terdiri dari 10 pernyataan. Hasil dari uji ahli isi mendapatkan kesimpulan bahwa isi dari pengenalan suku budaya indonesia sudah $100 \%$ sesuai dan tidak menyimpang dari cerita aslinya. Dan hasil Pelaksanaan uji ahli media yang merupakan dosen Undiksha di lakukan dalam 1 tahap, karenapengujian sudah $100 \%$ sesuai. Pada ahli media 2 pun demikian, dimana tahap pengujian dilakukan 1 tahap dengan hasil pengujian $100 \%$ sesuai.Pada uji ahli media ini peneliti menggunakan rumus Gregory, hasil perhitungan sebagai berikut .

Validitas $=\frac{D}{A+B+C+D}=\frac{20}{20}=1,0$ 
ISSN 2252-9063

Berdasarkan perhitungan hasil Uji Ahli pada media pembelajaran pengenalan suku budaya didapat hasilnya yaitu 1 yang berarti validitas sangat tinggi.

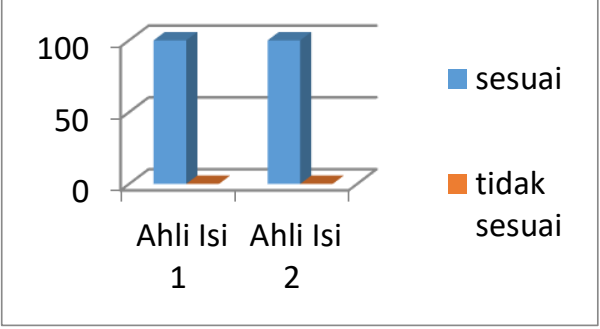

Gambar 15 Uji Ahli Isi

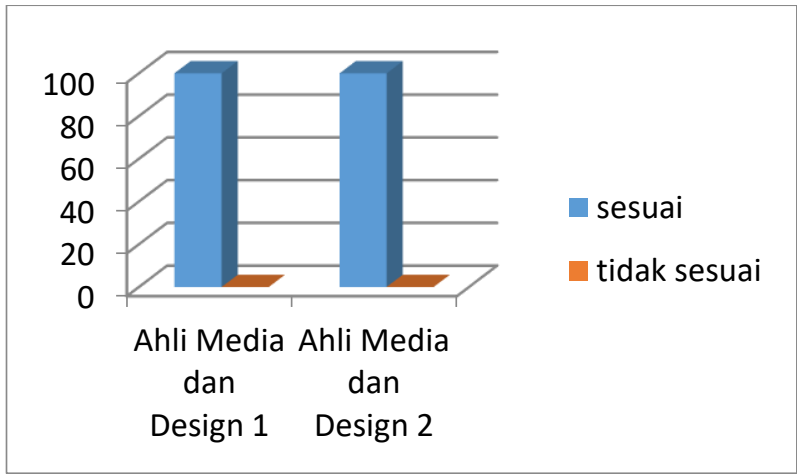

Gambar 16 Uji Ahli Media dan Design

- Hasil respon guru

Pelaksanaan pengujian respon oleh guru di lakukan dengan guru sekolah dasar yaitu dengan ibu Siti Aisyah dengan representasi poin sebesar $92 \%$.

$$
\bar{x}=\frac{\sum x}{N} .
$$

Keterangan:

$\bar{x}=$ Rata - rata kelas untuk skor respon guru dan siswa

$\sum x=$ Jumlah skor respon guru siswa

$\dot{N}=$ Banyaknya guru dan siswa

Sedangkan untuk mencari mean ideal (Mi) dan standar deviasi ideal (SDi) digunakan rumus sebagai berikut:

$M i=\frac{1}{2}($ skor maksimal ideal + skor terendah ideal..

$S D i=\frac{1}{6}($ skor tertinggi ideal - skor terendah ideal $)$ nilai

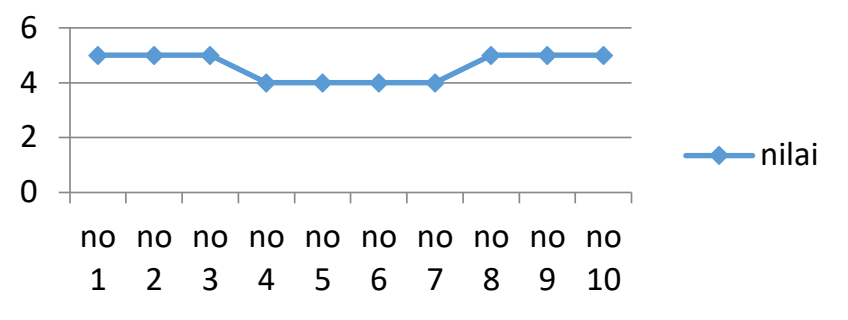

Gambar 17. Nilai Respon Guru

- Hasil uji respon pengguna

Hasil dari respon pengguna dilakukan untuk mengetahui kepuasan dan tanggapan pengguna tentang media pembelajaran pengenalan suku dan budaya indonesia. uji respon pengguna dilakukan dengan cara menyebarkan angket kepada 30 orang siswa kelas 4 MIN singaraja. hasil perhitungan responden pengguna sebagai berikut.

$p \quad=$ Persentase

$f \quad=$ Frakuensi dari setiap jawaban angket / jumlah total

$n \quad=$ Jumlah skor ideal

$100=$ Bilangan tetap

Persentase Hasil $=2672 / 30$

$=89,07 \%$

Berdasarkan perhitungan hasil Respon Pengguna media pembelajaran pengenalan suku budaya indonesia didapatkan persentase sebanyak $89,07 \%$ yang berarti hasil respon dalam rentangan Sangat positif.

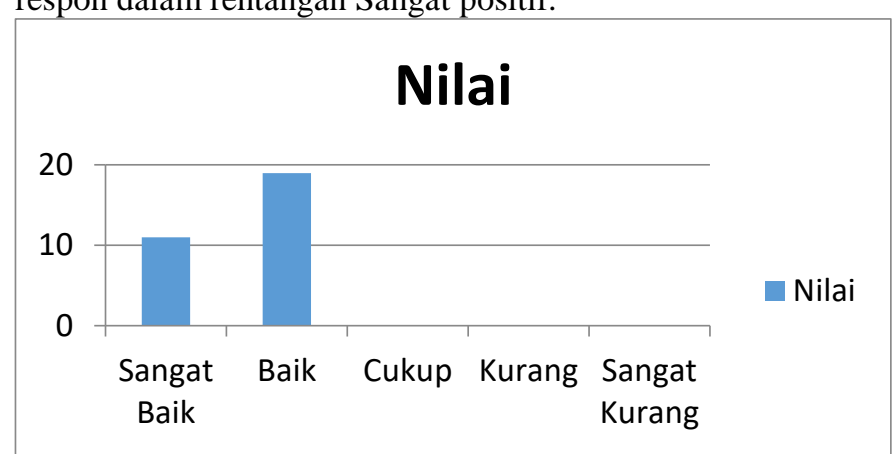

Gambar 18 Hasil Nilai Respon Pengguna

- $\quad$ Hasil uji efektifitas

Pada pengujian efektifitas peneliti menggunakan soal pre test dan post test, dengan hasil pre tets rata-rata $62 \%$. Dengan nilai efektifitas kurang dari cukup. Setelah siswa menonton video pembelajaran suku budaya Kemudian di lakukan pengujian post test, nilai post test yang di hasilkan sevesar 89 $\%$ yang berarti pembelajaran yang di buat sangat efektif. Selanjutnya mencari nilai $\mathrm{N}$ - Gain dimana di dapat nilai $\mathrm{N}$ gain sebesar $0,71 \%$ dengan nilai efektifitas Tinggi. Rumus perhitungam efektifitas : 


$$
\begin{aligned}
& N-\text { Gain }=\frac{\text { Skor Posttest }- \text { Skor Pretest }}{\text { Skor Maksimal }- \text { Skor Pretest }} \\
& N-\text { Gain }=\frac{89,3-62,67}{100-62,67}=0,71 \%
\end{aligned}
$$

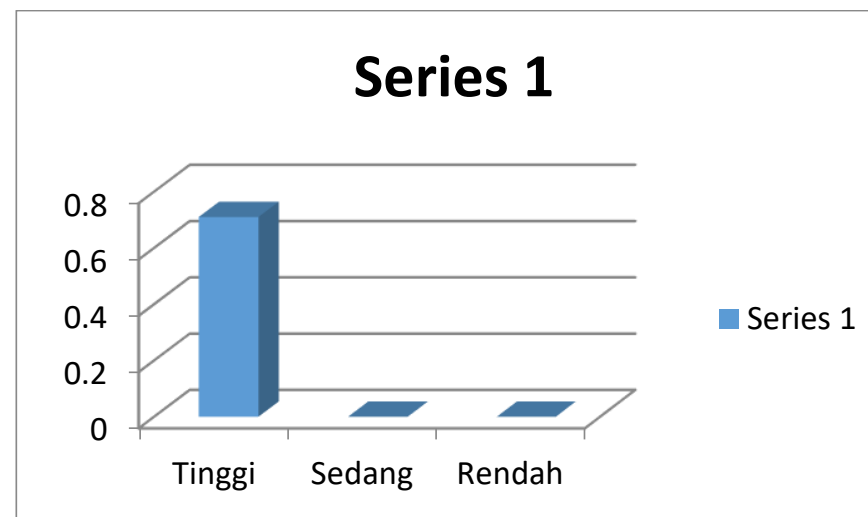

Gambar 19 Hasil Perhitungan N - Gain

Tabel 1

\begin{tabular}{|c|c|}
\hline Indeks & Kriteria \\
\hline $0.70<\mathrm{g}<1.00$ & Tinggi \\
\hline $0.30<\mathrm{g}<0.70$ & Sedang \\
\hline Indeks & Kriteria \\
\hline $0.00<\mathrm{g}<0.30$ & rendah \\
\hline
\end{tabular}

\section{Pembahasan}

Pengembangan media video pembelajaran PPKn untuk pengenalan suku dan budaya indonesia ini menggunakan metode ADDIE. ADDIE adalah akronim dari Analysis, Design, Development, Implementation, dan Evaluation. Prosedur pengembangan dalam model ADDIE terdiri dari lima tahap. Kelima tahap tersebut adalah analyze (analisis), design (desain), develop (pengembangan), implement (implementasi), dan evaluate (evaluasi) (Anglada, 2007) Model ini merupakan model yang berlandasan pada pendekatan sistem yang efektif dan efisien serta prosesnya yang bersifat interaktif yakni hasil dari setiap fase dapat digunakan di fase berikutnya.

Tahap analisis merupakan tahap pertama yang harus dilakukan seperti pengumpulan informasi dan kebutuhan secara lengkap kemudian dianalisis dan didefinisikan kebutuhan yang harus dipenuhi oleh aplikasi atau media yang akan dibangun. Media pembelajaran yang dikembangkan diharapkan berguna bagi generasi muda untuk mengenal dan memahami suku dan budaya indonesia yang sudah mulai dilupakan oleh generasi muda. Untuk menarik perhatian pengguna, didalam media pembelajaran kita akan di sajikan video yang menggambarkan pada dunia nyata, seperti rumah adat, suku.

Berdasarkan hasil wawancara dengan ibu Siti Rahmayanti Spd.SD yang merupakan guru SD kelas IV MIN Singaraja, menurut beliau pelajaran PPKn khususnya di materi suku dan budaya indonesia merupakan langkah awal untuk generasi muda untuk mengenal suku dan budaya yang ada di indonesia sehingga menimbulkan rasa cinta dalam melestarikan suku dan budaya yang ada di indonesia. Oleh karena itu, pelajaran PPKn untuk pengenalan suku dan budaya indonesia di ajarkan di jenjang pendidikan SD atau MIN.

Dari hasil observasi dan wawancara awal ditemukan permasalahan pada pembelajaran pendidikan pancasila dan kewarganegaraan (PPKn) kelas 4 MIN Singaraja yang dimana siswa sulit untuk memahami materi keanekaragaman suku bangsa, media pembelajaran yang kaku yang berupa gambar, kurang mampu untuk menambah semangat dan memberikan contoh yang jelas, sehingga tujuan pembelajaran tidak optimal.

Berdasarkan analisis masalah tersebut maka solusi yang dapat peneliti usulkan adalah dengan mengembangkan sebuah video pembelajaran PPKn untuk pengenalan suku dan budaya indonesia. Pengembangan media ini dirasa akan membantu karena dalam video pembelajaran pengenalan suku budaya yang diusulkan akan menampilkan sebuah gambar yang bergerak atau video yang memberikan contoh - contoh keberagaman indonesia dan suku budaya indonesia seperti suku, rumah adat, pakaian adat, tarian, alat musik yang sesuai dengan kenyataan. Serta mampu menjelaskan masing - masing contoh suku budaya yang ada di indonesia.

Penelitian terkait seperti [3] yang berjudul "Multimedia Interaktif Bermuatan Keanekaragaman Budaya Indonesia pada Pembelajaran Tematik untuk Meningkatkan Rasa Cinta Tanah Air Siswa Sekolah Dasar".penilitian ini Memiliki respon yang baik dari siswa, Respon siswa terhadap multimedia interaktif melalui angket respon siswa, menunjukkan bahwa kualitas multimedia interaktif yang dikembangkan tergolong dalam kriteria baik sekali. Penelitian terkait juga dilakukan oleh [4] dengan judul "Pengembangan Media Video Pembelajaran Untuk Mengembangkan Karakter Disiplin Siswa di SDN Adisucipto 02". Hasil penelitian menujukkan bahwa: penilaian ahli materi memperoleh skor rata-rata $(4,9)$ dan termasuk dalam kategori sangat layak, penilaian ahli media memperoleh skor rata-rata $(4,7)$ dan termasuk kategori sangat layak, uji coba perorangan memperoleh skor rata-rata $(4,5)$ dan termasuk kategori sangat layak, uji coba kelompok kecil memperoleh skor rata-rata $(3,9)$ dan termasuk kategori layak, uji coba lapangan memperoleh skor rata-rata $(4,18)$ dan termasuk kategori sangat layak dan segi keefektifan media video karakter disiplin berdsarkan tes kedisiplinan menujukkan kategori siswa yang sudah melaksanakan kedisiplinan dengan baik sebanyak 19 dari 22 siswa $(86,37 \%)$. Berdasarkan permasalahan yang terjadi dan beberapa solusi yang pernah di gunakan 
sebelumnya, dirasa perlu adanya media untuk menunjang proses pembelajaran tentang keanekaragaman suku dan budaya Indonesia.

Pada tahap desain, peneliti melakukan perancangan konten video yang akan ditampilkan di pada media pembelajaran, perancangan antarmuka, dan perancangan evaluasi untuk setiap tahapannya. Proses evaluasi pada tahap ini peneliti melakukan dua pengujian yaitu uji ahli media dan uji ahli isi. Ahli media pada yang peneliti libatkan dosen di jurusan Pendidikan Teknik Informatika Undiksha. Fokus penilaian pada uji ahli media ini adalah kesesuaian pemilihan jenis huruf, kesesuaian pemilihan ukuran huruf dan kesesuaian komposisi warna huruf dengan warna latar. Gerakan video dan tampilan secara keseluruhan pada pembukaan dan penutupan video pada media.

Tahap implementasi adalah tahap saat media telah siap untuk diperkenalkan dan dilakukan pengujian kelayakan. Pada tahap ini dilakukan implementasi media pembelajaran pengenalan suku budaya indonesia pada siswa kelas IV MIN Singaraja yang akan dijadikan responden. Pada evaluasi tahap ini lebih difokuskan pada hasil dan isi dari tahap pengembangan seperti pengembangan antarmuka dan hasil pengembangan konten aplikasi. Hasil pengembangan secara isi di uji Validitas oleh para ahli isi. untuk mengetahui kesesuaian media yang di rancang dengan isi. Dan hasil yang di dapat dari uji validitas oleh ahli isi yaitu kesesuaian sebanyak $100 \%$. Ini menandakan bahwa isi dari media sudah sesuai dengan ajaran pembelajaran PPKn kelas IV MIN / SD.

Evaluasi pada tahap implementasi juga dievaluasi oleh ahli media yang pada penelitian ini peneliti melibatkan dosen dari jurusan Pendidikan Teknik Informatika Undiksha. Indikator pengujian pada tahap implementasi ini adalah kesesuaian video, kesesuaian pengambilan gambar, dan penggunaan. Dalam pengujian ini peneliti melakukan pengujian sebanyak 1 kali, peneliti mendapat kesesuai sebesar $100 \%$ yang menandakan bahwa rancangan dan hasil sudah sangat sesuai. Namun demikian, saran masih diberikan oleh ahli media yaitu lebih semangat dalam mengembangkan media sejenis.

Tahap evaluasi yang peneliti lakukan selanjutnya adalah evaluasi ahli isi tahap implementasi. Evaluasi ahli isi ini memfokuskan penilaian pada isi materi dari media mengenai contoh suku dan budaya indonesia dan keberagaman indonesia. Dalam penelitian ini juga, peneliti melakukan pengujian sebanyak 1 kali, peneliti mendapat kesesuaian sebanyak $100 \%$ yang menandakan bahwa rancangan dan hasil sudah sangat sesuai.

Setelah melakukan uji validitas, uji ahli isi dan ahli media. Peneliti juga melakukan uji oleh guru, hal ini dilakukan untuk mengetahui kesesuaian media yang di bangun dengan pembelajaran yang guru terapkan di sekolah. Dalam pengujian ini peneliti melibatkan guru PPKn dari MIN yang juga merupakan tempat penelitian. Dan hasil dari uji guru ini, peneliti mendapatkan hasil kesesuaian sebesar $92 \%$ dengan kategori "Sangat Baik".

Evaluasi tahap akhir pada penelitian ini dilakukan untuk mengetahui respon pengguna setelah menggunakan media yang peneliti kembangkan dengan melakukan uji respon pengguna. Jumlah responden yang peneliti gunakan dalam pengujian respon ini adalah 30 orang. Dari hasil analisis uji respon pengguna tersebut didapatkan rata-rata persentase respon dari 30 orang responden yaitu sebesar $89.07 \%$.

Peneliti menyebarkan angket Pre Test dan angket Post Test pada beberapa kelompok kecil. Dan hasil yang di dapat dari pembagian soal pree test dan post test yaitu peningkatan kemampuan anak-anak dalam memahami teori, dan contoh contoh suku adat indonesia. Dengan representasi awal sebelum di adakannya media sebesar $62,67 \%$ kemudian setelah di lakukan pemutaran media sebanyak 1 kali pertemuan, peneliti kembali menyebarkan angket pot test dan di dapatkan hasil sebesar $89,3 \%$.

Pada pengembangan media pembelajaran pengenalan suku budaya indonesia, peneliti mendapat beberapa kendala yang diantaranya adalah keterbatasan hadware (PC) yang mengakibatkan proses editing video menjadi lama dan keterbatasan hadware berupa alat dabing yang mengakibatkan kurang maksimalnya kualitas audio pada media. Serta kekurangan kamera yang mengakibatkan sudut pandang pengambilan gambar menjadi sedikit. Untuk tipe kamera sendiri peneliti menggunakan kamera Canon 1300D dan Canon $600 \mathrm{D}$, hasil video akan lebih bagus jika peneliti menggunakan kamera Canon 60D. Tapi karena kendala biaya, peneliti tidak mampu untuk menggunakan kamera 60D sesusai dengan rancangan awal yang peneliti harapkan.

Peneliti juga mendapat kendala pada tiga tempat untuk lokasi pembuatan video pembelajaran PPKn pengenalan suku dan budaya indonesia, di lokasi taman nusa, contoh suku yang budaya yang yang di tampilkan sangat sedikit di waktu normalnya, sehingga peneliti harus menunggu orang yang booking tempat taman nusa untuk mendapatkan contoh suku budaya yang banyak seperti tarian pendet, tari barong, pakaian adat jawa tengah dan sebagainya. Di lokasi taman soekarno, peneliti mendapat kendala banyaknya kendaraan yang lewat, sehingga suara video yang dibuat menjadi tidak maksimal, terakhir dimana lokasi di dalam kelas peneliti harusnya menggunakan kelas SMA 2 Muhammmadiyah Singaraja untuk pembuatan video, karena saat pembuatan video sekolah libur, peneliti tidak bisa menggunakan ruangan tersebut dan terpakasa menggunakan ruangan kelas di FTK 4.

\section{SIMPULAN}

Pengembangan video pembelajaran PPKn untuk pengenalan suku budaya indonesia menggunakan metode ADDIE (Analyze, Design. Development, Implementasi, and 
ISSN 2252-9063

Kumpulan Artikel Mahasiswa Pendidikan Teknik Informatika

(KARMAPATI)

Evaluation). Dimana pada tahap analisis terdiri dari proses teknik pengumpulan data, sinopsis, kebutuhan fungsional, kebutuhan non fungsional, analisis alat, analisis STP dan analisis SWOT. Kemudian pada tahap design terdiri dari penyusunan jadwal, pembuatan design concept art, pembuatan storyboard, pemilihan pengisi suara, perekaman dialog, pembuatan Video, pembuatan musik dan efek suara. Tahap ketiga adalah kegiatan pengembangan (development) yang meliputi kegiatan penyusunan bahan ajar. Kegiatan pengumpulan bahan/materi bahan ajar, pembuatan gambargambar ilustrasi, pengetikan, dan lain-lain mewarnai kegiatan pada tahap pengembangan. Pada tahap implementasi yaitu melakukan tahap pengujian, dengan ujian pertama dilakukan pada uji validitas isi dan media dan mendapat nilai presentase sebesar $100 \%$. Kemudian dilanjutkan dengan uji ahli isi dan media dan mendapat nilai presentase $100 \%$ setalah melakukan uji validitas dan uji ahli, dilakukan pengujian selanjutnya yaitu uji respon guru hal ini dilakukan untuk mengetahui kesesuaian media yang di bangun dengan pembelajaran yang guru terapkan di sekolah. Dan hasil dari uji guru ini, peneliti mendapatkan hasil kesesuaian sebesar 92\% dengan kategori "Sangat Baik". Dan Respon pengguna yaitu siswa atau anak - anak terhadap media pembelajaran pengenalan suku budaya indonesia mendapatkan respon yang baik, mereka sangat tertarik dan antusias untuk melihat dan mempelajari suku budaya dengan cara menonton video animasi yang di tampilkan Dari hasil uji respon di lapangan terhadap 30 anak-anak yang di jadikan responden dalam melihat kelayakan media pembelajaran di dapatkan hasil sebesar $89.07 \%$ yang artinya media pembelajaran pengenalan suku budaya indonesia masuk kategori sangat baik.

\section{REFRENSI}

Depdiknas. (2007). Pedoman Teknis Penyelenggaraan Pos PAUD. Jakarta : Depdiknas

[2] Tamara, A. (2018). Aplikasi Pembelajaran Keanekaragaman Budaya dan Suku Untuk Siswa Kelas 5 SDI AL - AZHAR 7 Sukabumi. E Proceeding of Applied Science. 4(1) : 104 - 113. Tersedia Pada http://libraryeproceeding. telkomuniversity.ac.id/index.php/appliedscience/artic le/download/5995/5974. Di Akses (21 Mei 2018).

[3] Komalasari, MD. Wihaskoro, AM. (2018). Multimedia Interaktif Bermuatan Keanekaragaman Budaya Indonesia Pada Pembelajaran Tematik untuk Meningkatkan Rasa Cinta tanah Air Siswa Sekolah Dasar. Elementary School 5. 5(1) : 130 - 137. Tersedia pada http://upy.ac.id/ojs/index.php /ES/article/download/1131/922. Di Akses (21 Mei 2018 )

[4] Hakim, L. (2017). Pengembangan Media Video Pembelajaran Untuk mengembangkan Karakter
Disiplin Siswa di SDN Adisucipto 02. Skripsi Universitas Negeri Yogyakarta. Tersedia Pada http://eprints.uny.ac.id 153424/1/Lukmanul\%20Halkim_10105244024.pdf. Di Akses (21 Mei 2018).

[5] Winaputra, US. (2006). Materi dan pembelajaran $P K n$ SD. Jakarta : Universitas Terbuka

[6] Suparlan, P. (2003). Bhineka Tunggal Ika : Keanekaragaman Sukubangsa atau Kebudayaan. Makalah dalam Seminar "Menuju Indonesia Baru : Dari Masyarakat Majemuk ke Masyarakat Multikultural", Perhimpunan Indonesia Baru dan Asosiasi Antropologi Indonesia. Yogyakarta, 16 Agustus 2001. Tersedia Pada http://journal.ui.ac.id/index.php/jai/article/viewFile/3 472/2752. Di Akses (27 Juni 2018).

[7] Kementrian Pendidikan dan Kebudayaan (Kemdikbud). (2016). Analisis Kearifan Lokal Ditinjau dari Keragaman Budaya. Tersedia Pada http://publikasi.data.kemdikbud.go.id/uploadDir/isi F9B76ECA-FD28-4D62-BCAEE89FEB2D2EDB .pdf. Di akses (27 Juni 2018).

[8] Mukmiman, (2008). Pengembangan Media Pembelajaran. Universitas Negeri Yogyakarta

[9] Busyaeri, A. (2016). Pengaruh Penggunaan Video Pembelajaran Terhadap Peningkatan Hasil Belajar MAPEL IPA di MIN Kroya Cirebon.Tersedia Pada https://syekhnurjati.ac.id/jurnal/index.php/ibtida/artic le/download/584/512. Di akses (17 Juni 2019)

[10] Syeful Bahri Djamarah dan Aswan Zain. (2010). Strategi Belajar Mengajar, Jakarta : PT Rineka Cipta.

[11] Bambang Eka Purnama. (2005). Proses Pembuatan Film, Indonesia Jurnal on Computer Scoence - Speed 4 Volume 1 Nomor 1 Desember 2007, ISSN 1979 9330 